\title{
Effectiveness of Print and Audiovisual Media in Breast Cancer Education to High-School Students
}

\author{
Amanda Carissa Wardhani, ${ }^{1}$ Sri Yusnita Irda Sari, ${ }^{2}$ Dharmayanti Francisca Badudu ${ }^{3}$ \\ ${ }^{1}$ Faculty of Medicine Universitas Padjadjaran, ${ }^{2}$ Department of Public Health Faculty of Medicine \\ Universitas Padjadjaran, ${ }^{3}$ Department of Surgery Faculty of Medicine Universitas Padjadjaran/Dr. \\ Hasan Sadikin General Hospital, Bandung, Indonesia
}

\begin{abstract}
Background: Breast cancer education could be a non-formal education to achieve a proper understanding about early detection of breast cancer. Optimal results need right methods and instruments. Recently, technology development can be implemented to support the non-formal education process. The purpose of this study was to determine the effectiveness between print and audiovisual media in health education on prevention and early detection of breast cancer.

Methods: It was a quasi-experimental study, comparing two intervention and one control groups, which was carried out from August to November 2013. The population was senior high school students in Jatinangor subdistrict West Java, Indonesia. The sample was taken by cluster sampling method; each group consisted of 120 female students. Students from Sekolah Menengah Atas Negeri Jatinangor were given printed media, students from Sekolah Menengah Kejuruan Padjadjaran were given audiovisual media and students from Pesantren Al Ma'soem as control group were not given any intervention. The knowledge of respondents was measured with pre-test and post-test questioner. Mean scores of knowledge were further analyzed by paired and independent t-test.

Results: The average of pre-test between intervention and control groups were similar $(8.125,8.725$ and 8.450 , respectively). The result showed that the average scores of post-test increased compared to pre-test both in the print and audiovisual media group $(\mathrm{p}=0.001)$.

Conclusions: Print and audiovisual media can increase the knowledge of respondents on prevention and early detection of breast cancer. However, audiovisual media is more effective as a tool for health education especially among teenagers.
\end{abstract}

Keywords: Audiovisual, breast cancer education, effectiveness, print media

\section{Introduction}

Breast cancer is the most common type of cancer among women worldwide and the global incidence of breast cancer increases annually.111 The majority of breast cancer patients come to the hospital in advanced stages, indicating that awareness and knowledge about breast cancer is still low as well as negative social-cultural perception of the disease. .-6, $6,11^{-11}$

It is difficult to know the signs and symptoms of breast cancer because it is rarely painful. The easier way of early detection for breast cancer is breast self-examination. ${ }^{3-9,11}$ Early treatment of breast cancer will likely lead to get better prognosis.
Furthermore, education to society to give better understanding about breast cancer is needed to prevent breast cancer especially to young woman. ${ }^{4-8,11}$ Breast cancer education could be a non-formal education to increase knowledge to achieve a proper understanding toward breast cancer. To get optimal results of breast self-examination, right methods and instruments are needed. ${ }^{10-12}$ Recently, current development of technology can be implemented to support the education process, for instance through media such as leaflets or audiovisual means. The purpose of this study was to get information about differences of breast cancer education effectiveness between the use of print and audiovisual media to high school female students in Jatinangor subdistrict, West Java, Indonesia.

Correspondence: Amanda Carissa Wardhani, Faculty of Medicine, Universitas Padjadjaran, Jalan Raya BandungSumedang Km.21, Jatinangor, Sumedang, Indonesia, Email: amandacwardhani@gmail.com 


\section{Methods}

A quasi experimental study was conducted for 4 months (August-November 2013). Data were collected from female highschool students in Jatinangor district. The participants were divided into 3 groups; two groups were experimental groups and one was the control group. Participants in the experimental group received breast cancer education, one group received leaflets (print media) as the education material while the other group received education through audiovisual aids. Participants assigned to the control group received none. Three schools were selected from a total of 10 high-schools in Jatinangor using simple random sampling, then 120 second grade students were selected as the study participants which consisted of 40 students of each school.

A set of questionnaire was used to assess the knowledge before and after the interventions in both experimental and control groups. Before breast cancer education, the experimental group and the control group received a pretest questionnaire. One week after the breast cancer education program, a post-test was applied to the experimental groups.

The questionnaire contained definition, risk factor, sign symptom and treatment of breast cancer, and was then validated before the intervention to 21 female students in highschools which were not selected in the study (Cronbach's alpha $=0.685$ ). The questionnaire consisted of 20 statements which assessed their knowledge about breast cancer and the common risk factors of breast cancer. A correct answer was assigned one point, whereas a wrong answer was scored zero. The results were calculated as frequencies of the correct answer out of the total answer of the same question and analyzed by paired t-test for each method in pre and post-test results, and independent t-test for post-test both interventions using print and audiovisual media.

Table 1 Data Distribution Based on Respondent's Characteristics

\begin{tabular}{lcc}
\hline \multicolumn{1}{c}{ Variables } & Frequencies (n) & Percentage (\%) \\
\hline Age (years old) & 11 & \\
15 & 81 & 9.0 \\
16 & 26 & 66.4 \\
17 & 118 & 22.0 \\
Total & & 100 \\
Level of mother's education & 34 & \\
Elementary School graduated & 18 & 28.8 \\
Junior High School graduated & 34 & 15.3 \\
Senior High School graduated & 32 & 28.8 \\
Diploma/bachelor & 118 & 27.1 \\
Total & & 100 \\
Family Income (Rp) & 23 & 19.5 \\
$<1,050,000,00$ & 41 & 34.7 \\
1,050,000,00-2,000,000,00 & 25 & 21.2 \\
$2,000,000,00-6,000,000,00$ & 29 & 24.6 \\
$>6,000,000,00$ & 118 & 100 \\
Total & & \\
Family history of breast cancer & 104 & 88.1 \\
No & 14 & 11.9 \\
Yes & 118 & 100 \\
Total & &
\end{tabular}


Table 2 Knowledge Score Level

\begin{tabular}{lccc}
\hline \multicolumn{1}{c}{ Intervention } & \multicolumn{1}{c}{ SD } \\
\hline Leaflet & Pre-test & 8.125 & 2.681 \\
& Post-test & 14.025 & 2.674 \\
Audiovisual & Pre-test & 8.725 & 3.273 \\
& Post-test & 15.225 & 2.177 \\
Control & & 8.450 & 2.773 \\
\hline
\end{tabular}

Note: $\mathrm{x}^{-}=$Mean; $\mathrm{SD}=$ Standard Deviation

The intervention using leaflets was adopted from a leaflet about breast cancer education and prevention which was developed by an oncology team from the Department of Surgery, Dr. Hasan Sadikin General Hospital. Furthermore, the intervention using

Table 3 Knowledge Score Level for Correct Answer about Breast Cancer according to Leaflet, Audiovisual and Control Group

\begin{tabular}{|c|c|c|c|c|c|}
\hline \multirow{2}{*}{ Statement } & \multicolumn{2}{|c|}{ Leaflet(\%) } & \multicolumn{2}{|c|}{ Audiovisual(\%) } & \multirow{2}{*}{$\begin{array}{c}\text { Control } \\
(\%)\end{array}$} \\
\hline & Pre & Post & Pre & Post & \\
\hline Breast cancer is a communicable disease & 67.5 & 82.5 & 82.5 & 100 & 80 \\
\hline Breast cancer is all lump found in breast & 45 & 45 & 40 & 50 & 25 \\
\hline Breast cancer is not a curse disease & 90 & 80 & 72.5 & 72.5 & 77.5 \\
\hline $\begin{array}{l}\text { A woman who get menarche under age } 12 \text { has higher risk } \\
\text { of breast cancer }\end{array}$ & 5 & 82.5 & 5 & 87.5 & 0 \\
\hline $\begin{array}{l}\text { A woman who has child will have higher risk of breast } \\
\text { cancer }\end{array}$ & 42.5 & 72.5 & 42.5 & 72.5 & 40 \\
\hline $\begin{array}{l}\text { A woman who gave birth to her first child after } 30 \text { years old } \\
\text { will get higher risk of breast cancer }\end{array}$ & 10 & 15 & 25 & 12.5 & 15 \\
\hline $\begin{array}{l}\text { A woman who has never breastfed or breastfeeding her } \\
\text { children will get more risk of breast cancer }\end{array}$ & 17.5 & 80 & 35 & 95 & 50 \\
\hline $\begin{array}{l}\text { A woman who has a mother or sister who had breast } \\
\text { cancer are more at risk of breast cancer }\end{array}$ & 32.5 & 82.5 & 35 & 95 & 35 \\
\hline $\begin{array}{l}\text { A woman who consumed a low-fat diet is more at risk of } \\
\text { breast cancer }\end{array}$ & 22.5 & 70 & 47.5 & 57.5 & 22.5 \\
\hline Smoking increases the risk of breast cancer in women & 65 & 90 & 55 & 87.5 & 67.5 \\
\hline $\begin{array}{l}\text { Alcohol consumption increases the risk of breast cancer in } \\
\text { women }\end{array}$ & 55 & 87.5 & 52.5 & 95 & 47.5 \\
\hline $\begin{array}{l}\text { Breast cancer more experienced among women older than } \\
40 \text { years }\end{array}$ & 32.5 & 50 & 40 & 90 & 17.5 \\
\hline $\begin{array}{l}\text { A lump in the breast is one of early symptoms of breast } \\
\text { cancer }\end{array}$ & 60 & 97.5 & 82.5 & 100 & 85 \\
\hline Lump caused by breast cancer always feels pain & 0 & 15 & 7.5 & 32.5 & 10 \\
\hline One sign of breast cancer is nipple will be retracted & 20 & 92.5 & 15 & 100 & 22.5 \\
\hline $\begin{array}{l}\text { Breast cancer can be overcome only by surgical removal of } \\
\text { the lump }\end{array}$ & 15 & 45 & 17.5 & 40 & 10 \\
\hline Breast cancer is difficult to cure & 27.5 & 40 & 40 & 47.5 & 25 \\
\hline Self-breast examination can detect breast cancer earlier & 72.5 & 100 & 47.5 & 95 & 77.5 \\
\hline Self-breast examination require a lot of money to perform & 37.5 & 75 & 37.5 & 97.5 & 47.5 \\
\hline Healthy lifestyle can reduce the risk of breast cancer & 95 & 100 & 92.5 & 95 & 90 \\
\hline
\end{tabular}


Table 4 Comparison of Level of Knowledge between Pre-test and Post-test Intervention $(n=40)$

\begin{tabular}{|c|c|c|c|c|c|c|}
\hline \multirow{3}{*}{ Intervention } & \multicolumn{4}{|c|}{ Correct answer } & \multirow{3}{*}{$\begin{array}{c}\text { T test } \\
\text { paired }\end{array}$} & \multirow{3}{*}{ p-value } \\
\hline & \multicolumn{2}{|c|}{ Pre-test } & \multicolumn{2}{|c|}{ Post-test } & & \\
\hline & $\bar{x}$ & SD & $\bar{x}$ & SD & & \\
\hline Leaflet & 8.125 & 2.681 & 14.025 & 2.674 & -12.533 & 0.001 \\
\hline Audiovisual & 8.725 & 3.273 & 15.225 & 2.177 & -13.722 & 0.001 \\
\hline
\end{tabular}

Note: $\bar{x}=$ Mean; $\mathrm{SD}=$ Standard Deviation

audiovisual media was developed by the researcher under supervision of an oncologist from Dr. Hasan Sadikin General Hospital.

Informed consent was given to all participants before the interventions and ethical approval from the Health Research Ethics Committee, Faculty of Medicine of Universitas Padjadjaran was obtained before the study was conducted.

\section{Results}

The total number of respondents of this study was 120 respondents; however data of two respondents were missing due to the incomplete questionnaires. Consequently, the actual number of respondents in this study was 118 respondents.

The youngest age was 15 years while the oldest age was 17 years (mean=16.13 years old), the level of mother's education was mostly poor; the lowest family income was $19.5 \%$ below the regional minimum salary, otherwise, the highest family income was $34.7 \%$ above the minimum salary. In addition, $11.9 \%$ of the respondents admitted that there was a history of breast cancer in their family (Table 1).

The average score of post-test after the intervention of breast cancer education using both print and audiovisual media showed an improvement. The average knowledge before the intervention was almost similar among the use of leaflets, audiovisual aids and control group; 8.125, 8.725 and 8.450, respectively (Table 2).

Moreover, breast cancer education using leaflets (print media) or audiovisual aids mostly showed better score in the posttest. The most increasing score rate was on question number 4 which stated that"a woman who gets menarche under age 12 has higher risk of breast cancer". The correct answers in the pre-test were only $5 \%$ both in print media (leaflet) or audiovisual media group, afterward a significant increase by $82.5 \%$ was found remarkably at the post-test. On the other hand, there were correct answers in the similar scores between the pre-test and post-test which occurred on question number 2 which stated about "breast cancer is all lump found in breast" (Table 3 ).

The average score on the correct answers of the pre-test by use of leaflet (print media) was $8.125(\mathrm{SD}=2.681)$, and the mean score on the post-test was $14.025(\mathrm{SD}=2.674)$, also using audiovisual media was 8.725 ( $\mathrm{SD}=3.273)$, and the mean score on the post-test was 15.25 $(\mathrm{SD}=2.177)$. There was a significant increase between the pre and post-test using print (leaflet) and audiovisual media (Table 4).

A significant difference could be seen from the average of correct answers on the post-test with $\mathrm{p}=0.031$. Intervention using audiovisual media provided mean score at 15.225 , while intervention using leaflet presented an average of correct answers at 14.025 (Table 5)

Table 5 Comparison on Level of Knowledge after Intervention between Print and Audiovisual Media ( $n=40)$

\begin{tabular}{|c|c|c|c|c|c|c|}
\hline & \multicolumn{2}{|c|}{ Leaflet } & \multicolumn{2}{|c|}{ Audiovisual } & \multirow{2}{*}{$\begin{array}{c}\text { T test } \\
\text { paired }\end{array}$} & \multirow{2}{*}{ p-value } \\
\hline & $\overline{\mathbf{x}}$ & SD & $\bar{x}$ & SD & & \\
\hline Pre-test & 8.125 & 2.681 & 8.725 & 3.273 & -0.897 & 0.373 \\
\hline Post-test & 14.025 & 2.674 & 15.225 & 2.177 & -2.200 & 0.031 \\
\hline
\end{tabular}

Note: $\bar{x}=$ Mean; SD = Standard Deviation 


\section{Discussion}

Based on the study among high-school students in Jatinangor on health education, prevention and early detection of breast cancer, suggesting that an increase in knowledge was found after interventions both using print and audiovisual media. It showed that knowledge about health can be improved through health education. ${ }^{12}$

Based on the idea that we can increase the public health status, thus promotion activities must be prioritized through health education especially for teenagers, such as on prevention and early detection of breast cancer. The roles of educational method, for instance education by audiovisual aids was more effective than using leaflets. The theory on educational method stated that the more senses involved in receiving something, the more understanding we can gain. ${ }^{12}$ Useful educational method helps to stimulate sensory at the time of the submission of information on the education process, subsequently knowledge can be easily obtained. ${ }^{10}$

During the educational process, the community can acquire knowledge through a variety of educational tools. Proper tools should be selectively chosen to improve knowledge especially about the prevention and early detection of breast cancer for teenagers. ${ }^{10}$ The results showed the difference in the effectiveness of breast cancer prevention education using leaflets or audiovisual media to high-school students in Jatinangor. This difference could be seen from the average response on the post-test, education using leaflets got 14.025 while audiovisual aids got 15.225 (Table 4).

A leaflet (print media) is likely to provide clear and extensive information; consequently, the readers are able to store information in their memory. An interesting feature on the leaflet will be able to attract the student's interest. The advantage of the leaflet is that it can stimulate the senses of the eyes at the time of the educational process, besides it is a cost-effective and handy tool which can also be read many times as they wish. Moreover, it can be multiplied and distributed to relatives or close friends so that the information will be disseminated.

Audiovisual aids are proficient to improve the effectiveness in gaining knowledge and information. In addition, audiovisual applications have advantages in displaying real objects that do not exist physically. Besides cognitive learning, audiovisual aids will improve student's memory about materials given during the education process. ${ }^{17-20}$ The audiovisual media is able to stimulate the senses of vision and hearing at the time of delivery of educational material. Furthermore, audiovisual applications also have the ability to combine all the material circumstances, such as text, video, animation, images, graphics, and sound effects. It becomes a unified whole in the presentation. Display a fun interactive audiovisual application led to higher student interest rather than view the leaflet. ${ }^{13-16}$

The limitation of this study was the posttest which was taken only one week after the pre-test, it could be any differential memory in each respondent to remember what they had learned, and in addition the questionnaire was self- administered therefore recall bias might occur.

In conclusion, the audiovisual media is more effective than the print media as a tool for health education especially toward teenagers. Each leaflet or audiovisual aids has advantages, consequently a proper method should be chosen according to the time, place and situation of the audience. Education of reproductive health is important to be developed as part of the school's curriculum as a non-formal subject for teenagers.

\section{References}

1. Laveena, Karkada S. Effectiveness of an informational leaflet on knowledge regarding breast cancer among women of reproductive age. NUJHS. 2013;3(3):93-5.

2. Ramalingam $S$, Nivedhita $S$, Divya $P$, Madhurima P, Poonguzhali R. Knowledge and attitude about breast cancer selfexamination among school teacher in an urban area of Coimbatore. Asian Student Medical Journal. 2012;11(1):1-7.

3. Smith RA, Caleffi M, Albert US, Chen TH, Duffy SW, Franceschi D, et al. Breast cancer in limited-resource countries: early detection and access to care. Breast J. 2006;12 Suppl 1:516-26.

4. Kanaga KC, Nithiya J, Shatirah MF. Awareness of breast cancer and screening procedure among Malaysian women. Asian Pac J Cancer Prev. 2011;12(8):1965-7.

5. Rasjidi I. Deteksi dini \& pencegahan kanker pada wanita. Jakarta: Sagung Seto; 2009.

6. Radi SM. Breast cancer awareness among Saudi females in Jeddah. Asian Pac J Cancer Prev. 2013;14(7):4307-12.

7. Akhtari-Zavare $\mathrm{M}$, Juni $\mathrm{MH}$, Manaf RA, Ismail IZ, Said SM. Knowledge on breast cancer and practice on breast 
self examination among selected female University Student in Malaysia. Medical and Health Science Journal. 2011;7:49-56.

8. Grunfeld EA, Ramirez AJ, Richards MA. Women's Knowledge and Belief Regarding Breast Cancer. British Journal of Cancer. 2002;86(9):1376-7.

9. Wang HH, Chung YC, Sun JL. The effect of education program on knowledge and intention of breast cancer screening in Taiwan. Asian Pac J Cancer Prev. 2012;13(11):5545-9.

10. Khokher S. Qureshi W, Mahmood S, Saleem A, Mahmud S. Knowledge, attitude and preventive practices of women for breast cancer in the education institutions of Lahore, Pakistan. Asian Pac J Cancer Prev. 2011;12(9):2419-24.

11. Al-Dubai SA, Qureshi AM, Saif-Ali R, Ganasegeran K, Alwan MR, Hadi JI. Awareness and knowledge of breast cancer and mammography among a group of Malaysian women in Shah Alam. Asian Pac J Cancer Prev. 2011;12(10):2531-2.

12. Notoatmodjo S. Promosi kesehatan \& ilmu perilaku. Jakarta: Rineka Cipta; 2007.

13. Parsa P, Kandiah M. Breast cancer knowledge, perception and breast selfexamination practices among Iranian women. The International Medical Journal. 2005;4(2):20-3.

14. Ng CH, Pathy NB, Taib NA, Teh YC, Mun $\mathrm{KS}$, Amiruddin A, et al. Comparison of breast cancer in Indonesia and Malaysia
- a clinico-pathological study between Dharmais Cancer Centre Jakarta and University Malaya Medical Centre, Kuala Lumpur. Asian Pac J Cancer Prev. 2011;12(11):2945-6.

15. Keegan TH, DeRouen MC, Press DJ, Kurian AW, Clarke CA. Occurrence of breast cancer subtypes in adolescent and young adult women. Breast Cancer Res. 2012;14(2):R55.

16. Handayani S, Sudarmiati S. Pengetahuan remaja putri tentang cara melakukan SADARI. Journal Nursing Studies. 2012;1(1):93-100.

17. Pujiyanti A, Trapsilowati W, Suwasono H. Perbandingan dua metode pembelajaran tentang demam berdarah dungue pada guru Sekolah Dasar. Media Litbang Kesehatan. 2012;22(4):173-80.

18. Salimar, Mulyati S, Agus T, Dewi R. Peran penyuluhan dengan menggunakan leaflet terhadap perubahan pengetahuan dan sikap ibu balita gizi kurang. PGM. 2009;32(2):122-30.

19. Montqomery AA, Fahey T, Peter TJ. A factorial randomised controlled trial of decision analysis and an information video plus leaflet for newly diagnosed hypertensive patient. $\mathrm{Br} \mathrm{J}$ Gen Pract. 2003;53(491):446-53.

20. Zakrzewska JM. Research Summary: The impact of patient information leaflets. $\mathrm{Br}$ Dent J. 2003;194(12):683-8. 